\title{
The Role of Parents in Improving the Behavior of School's Students in Azena Primary School, Ethiopia
}

\author{
Gedifew Sewenet Yigzaw ${ }^{1}$
}

\begin{tabular}{l} 
ARTICLE INFO \\
\hline Article History: \\
Received:19.12.2018 \\
Received in revised form: \\
28.02.2019 \\
Accepted: \\
Available online: 01.07 .2019
\end{tabular}

\section{INTRODUCTION}

Education is a process of learning which is aimed at improving moral, cultural and intellectual attributers of students individually as well as a member of social group. The process of learning is looked at as training in the field of morals for individuals through which their potentialities are developed; the traits of the cultures are inculcated in them and the culture of the people is transmitted to the coming generations. It is an instrument to change the social, cultural, economic and political set up of the society. It is considered as a key to development (Tadesse, 2014). Moreover, it can prepare ideal citizens to transform the irrational structure of society to rational one and can serve as a permanent source of human power for the development of a country. How erver, in preparing the ideal citizens, the role of parents is pivotal because family is the first agent of socialization to inculcate the conscience of good and bad (Grusec, 2011). Therefore, involvement of parents in primary educational institutions is a driving factor to shape the behaviour of students.

For many years, the importance and need for parental involvement in education has been well recognized (Ravitch, 2016). Parent's involvement can be understood as any action taken by a parent that can theoretically be expected to improve student performance or behavior. In other words, parent's involvement consists of those actions that help a child to meet or to exceed the norms or expectations of the student's role and encompasses parent-child, parent-teacher, and to some degree parent-parent relations (McNeal, 2014).

Furthermore, parent's involvement plays a vital role in implementing the operation of educational system. School can no longer set itself up without taking into consideration the active involvement of parents and the community. Students with involvement of parents in their school tend to have fewer behavioral problems and better academic performance and are more likely to complete high school than students whose parents are not involved in their school (Henderson \& Berla, 1994; McNeal, 2014).

\footnotetext{
${ }^{1}$ Senior Lecturer, corresponding e-mail: sge difew2010@gmail.com, orcid.org/0000-0003-3249-7587, Bahir Dar University, Ethiopia
} 
When schools, families and community groups work together to support learning, children tend to do better in school, stay in school longer, and like school more. Parental involvement over the past decade indicates that regardless of family income or background, students with involved parents are more likely to earn higher grades and test scores, attend school regularly, have better social skills, show improved behavior and graduate to postsecondary education (Henderson \& Mapp, 2002 as cited in Mwirichia, 2013).

Policy makers and educators are studying the escalation of parental-school collaboration as a method of improving educational success and socially accepted behavior for children (Newchurch, 2017). The student's behavioral problems, according to Glavin (2002), are considered as the most dangerous ones which face the components of the educational process in the school. Students that practice disruptive behaviors can cause disciplinary problems in the classroom and have negative impacts on other students.

The Ethiopian government has started to implement the "General Education Quality Assurance Package" from 2006 onwards. The program includes "Active Parent and Community Participation" as the main element of the quality assurance and considers parents and community as the stakeholders of education system. Because of this, schools are showing interest to w ork with parents and community, and need active participation of them to increase students' academic achievement and behavioral change (Ministry of Education (MoE), Federal Democratic Repubilic of Ethiopia (FDRE), 2016). The program realized that parents are the children's first and most important teachers. If children are to be successful in school, parents must participate actively in their children's behavioral lives. A lack of parental involvement impacts negatively on children's behavior and academic performance.

Parent's participation in their children's schooling frequently enhances children's selfesteem, improves children's academic achievement, improves parent-child relationships, and helps parents develop positive attitudes tow ards school and a better understanding of the schooling process (MOE, FDRE, 2016). Therefore, this study has tried to investigate the role of parents in shaping behaviour of school's students in Azena Primary School, Ethiopia.

\section{LITERATURE REVIEW}

\section{The Concept and Definition of Parental Involvement}

Ravitch (2016) recognized parent involvement as:

"The participation of parents in every facet of children's education and development from birth to adulthood."

Wilder (2014) reported that parental involvement was found to be one of the factors affecting student's achievement and student's behavior in the school. Parent involvement can be described as social relations that are imbued with norms of trust, obligation, or reciprocity (McNeal, 1999). If it is described in this manner, parent involvement is conceived as a form of social capital. Using this framew ork, McNeal contends that parent involvement encompasses three broad domains, parentchild relations, parent-school relations, and parent-parent relations. It is generally assumed that parents invest their time in their children and school personnel with the expectation that their involvement will yield a tangible return. Parent involvement is any action taken by a parent that can theoretically be expected to improve student's behavior (McNeal, 2014).

\section{Barriers to Parent Involvement}

While parents today are frequently inattentive when there are disturbances and pressures of daily life, many of them find it hard to attend school functions or become involved in the schooling of their children on a regular basis due to being burdened with long work hours, childcare, low income, and linguistic barriers (Okeke, 2014). Leitch and Tangri (2006) conducted a study in two high schools in Washington D.C. and found that parents who were employed were more involved than parents who were unemployed.

Lack of timeamong working parents, negative prior experiences with schools, inability of parents to help children with their homew ork, limited funding to support parent engagement activities, and lack of staff training in different strategies to engage parents were seen as potential barriers. Furthermore, parents may face language barriers, may not be aw are of school procedures and may not have transportation or child-care (EdSource, 2014).

In general, the potential barriers to parent involvement can be categorized into four areas. First, family factors, which include parents' beliefs about getting involved in their children's education; parents' 
attendance in school's events, parents' life context, and parents' backgrounds, such as social class, ethnicity, and gender. Second, factors related to the children's age, barriers in learning and disabilities, rew ards, and aptitudes, and also problems in attitude. Next, factors of the relationship between parents and teachers, related to managing purposes and schedules, interacting with other and using effective language. Finally, factors of the social environment related to historical and demographic, political and economic iss ues (Dwi Wulandary \& Herlisa, 2017).

\section{Types of Parent Involvement}

Parents, schools, and society partake in a mutual aw areness and commitment in instructing students (Epstein \& Sheldon, 2016). Epstein's school-family-partnership theory demonstrates and suggests that the stakeholders work cooperatively to influence the improvement and education of children. Epstein et al. (2009) described a framew ork to include six key types of involvement:

Parenting: By giving information and material that increases parent's awareness and strengthen their skills to influence their child's development and advancement, institutions can help families in attaining their responsibilities as parents/guardians of students at each age level (Epstein, 2013). Parents, according to Epstein, should provide a save and healthful learning environment with supervision and guidance as well as proper discipline. With effective child rearing skills in place, parents tend to have a better sense of support from the school and other parents.

Communication: It alludes to parent and school contact with respect to school curricula and student progress. Epstein, Galindo, and Sheldon (2011) characterized it as the capacity to plan compelling kinds of school-to-home and home-to-school collaborations about school and student progress. As parents speak with the school, they commonly turn out to be more agreeable and happy with the school and the ed ucators (Epstein et al., 2011).

Volunteering: It is comprised of supporting the mission and vision of the school and supporting the learning process in any capacity. Some of the sample practices include allowing parents to serve in school programs (Epstein, 2010b).

Learning at home: Families give reassurance to their children, and there is likelihood for the children to be more actively involved in setting goals for educational success, and in planning postsecondary educational experiences (Epstein, 2010a).

Decision-making: Schools are charged now to include parental representation in school governance so that parents have a voice in the decision-making process for school affairs.

Collaborating with the community: This refers the identification and combination of resources for assisting the school and families, as well as the community (Hall \& Quinn, 2014). Parent-student communication (regarding with school and values), holding high educational expectations, authoritative parenting style (Hill \& Tyson, 2009), and positive home-school interaction could play good contribution for the enhancement of affirmative student behavior in the school and thereby would foster student academic performance. İ this case, cooperative school governance is very important for the development of the school and for improving the bevavior of school's students. Hence, making coordination with the community, especially with parents, is an appropriate mechanism in the school because parents are the engines of their children.

\section{METHODOLOGY}

\section{Research Design}

This study employed both quantitative and qualitative research approaches. Creswell (2012) suggested that a mixed approach is a procedure for collecting, analyzing, and mixing both quantitative and qualitative methods in a single study or series of study to understand the research problems. According to Khotari (2006), the quantitative research approach involves the generation of data in quantitative form which can be subjected to rigorous quantitative analysis in a formal and rigid fashion whereas qualitative approach to research is concerned with subjective assessment of attitudes, opinions and behavior. Research in such a situation is a function of researcher's insights and impressions. Such an approach to research generates results either in non-quantitative form or in the form which are not subjected to rigorous quantitative analysis. Accordingly, in this study, qualitative approach provides a detailed description and understanding 
of intentions and behaviours whereas the quantitative approach provides hard data (numbers) so as to facilitate the analysis.

Thus, the study employed both approaches and applied descriptive survey research method because it helps to answ er questions concerning to the role of parental involvement on students' behavior, to illustrate the state of existing student discipline problems and can provide precise information concerning the parents' participation in education in the study area.

\section{Sources of Data}

In this study, the data were collected from both primary and secondary sources. The primary data were obtained from teachers and parents. Secondary data were obtained from thesis works, government reports, journal articles and related documents.

\section{Sample Size and Sampling Techniques}

The size of sample should neither be excessively large nor too small. It should be optimum. An optimum sample is one which fulfills the requirements of efficiency, representativeness, reliability and flexibility (Khotari, 2006). From this stand point, sufficient sample size has taken for this study because all 40 teachers were appropriately selected through census survey method. Accordingly, all 40 teachers were taken as respondents to fill the questionnaire and 10 parents were selected purposively for interview questions.

Table 1: Sample size and sampling techniques

\begin{tabular}{clll}
\hline No. & Target population & Sample taken & Sampling techniques \\
\hline 1 & Teachers & 40 & Census method \\
2 & Parents & 10 & Purposive \\
\hline
\end{tabular}

\section{Methods of Data Collection}

Questionnaires (both close and open-ended questions) was designed and administered to the teachers. Interview questions were prepared for parents so as to access qualitative data (see Annex 1 for sample questionnaire items). Document analysis was employed as complementary technique to collect the necessary data and to support the findings of the study.

\section{Methods of Data Analysis}

The micro-soft excel software application was used to generate the colomun chart of the demographic data of the respondents. The quantitative data were analyzed through frequency and percentages. In this process, incomplete questions and those in which respondents provided arguably misleading responses were discarded. Qualitative ideas were organized into concepts and presented through meaningful description.

\section{RESULTS AND DISCUSSION Demographic Information}

This part of the study highlights demographic data of the respondents, such as their gender, age and educational qualification.

According to figure $1,87.5 \%$ of teachers and $60 \%$ of parents were males. The remaining $12.5 \%$ of teachers and $40 \%$ of parents were females. Regarding to the age category, $50 \%$ of teachers and the largest percentages of parents (that is, $70 \%$ ) were found at the age range of $41-50$. While $35 \%$ of teachers and $30 \%$ of parents age was found between the ranges of 31-40. This indicates that most of respondents are matured enough so that they can provide valuable information for this study.

Concerning their educational qualification, the majority of parents (that is, $50 \%$ ) are 9 months certificate graduates and $30 \%$ of them are first degree graduates while $62.5 \%$ of teachers are diploma graduates; completed 3 years educational journey. The remaining $20 \%$ and $15 \%$ of teachers are certificate and first degree holders respectively. The research conducted by Papaoikonomou (2017) shows that the educational system is the major means of transmitting the knowledge and the values of every society. It constitutes the reproductive system of every society, shaping through its mechanisms the future citizens. 
From this, we can infer that educational qualification could play a vital role to enhance the desirable behavior of school's students in the study area.

The following figure clearly shows the demographic data of the respondents.

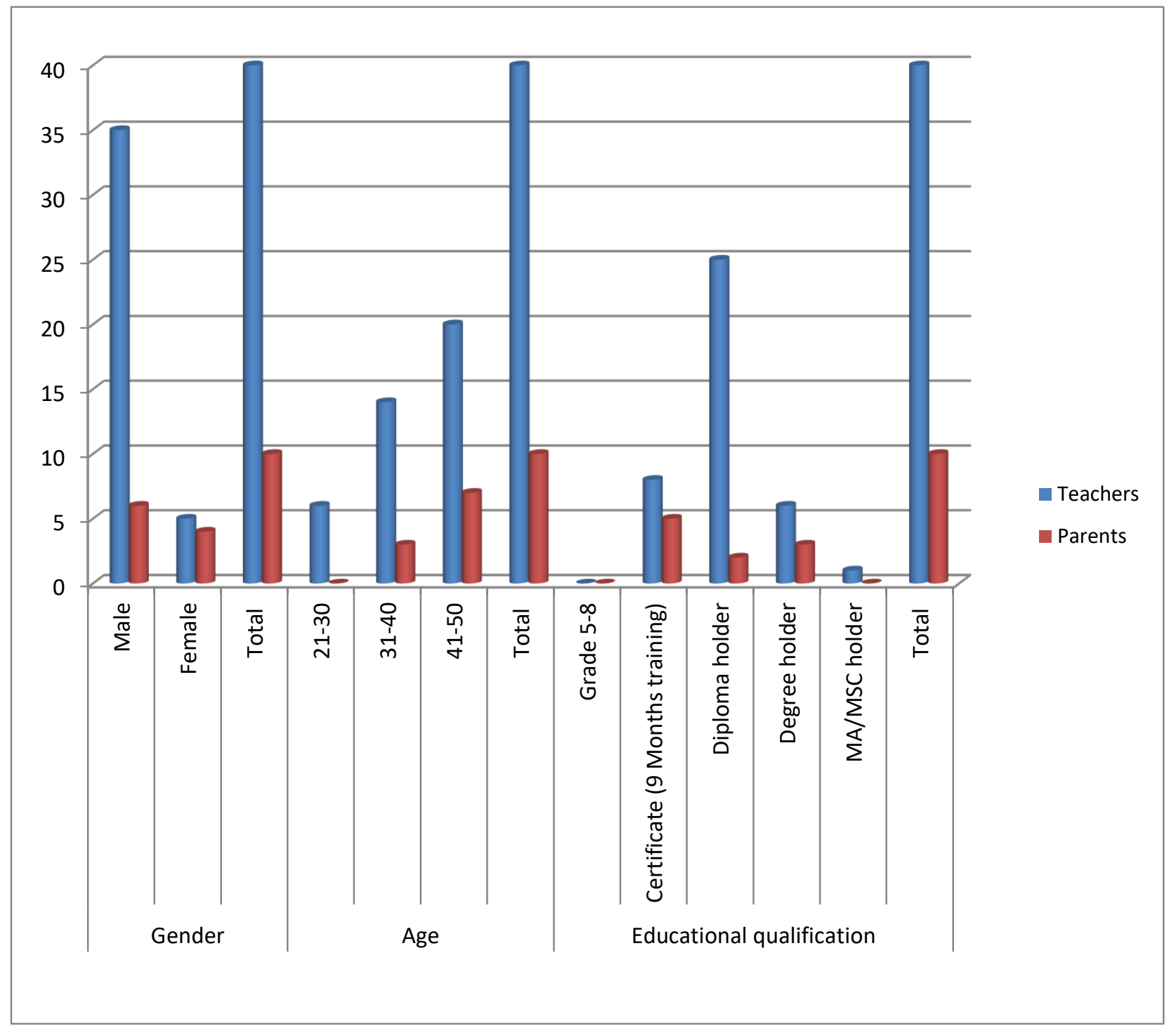

Figure 1: Democraphic data of selected respondents

The Level of Parental Participation

Table 2: Level of parent participation in improving student's behavior

\begin{tabular}{lllcc}
\hline No & Item & Alternatives & Responses of parents & Percentage (\%) \\
\hline 1 & The level of parental & High & 1 & 10 \\
& participation in improving & Medium & 2 & 20 \\
& students school behavior & Low & 7 & 70 \\
& & Total & 10 & 100 \\
\hline
\end{tabular}

As it has shown in table 2,70\% of the respondents revealed that the level of parents' participation in improving students' school behavior is low. İn this study, low participation implies that parents are not actively involving themselves in giving advices, delivering ethical trianings and counseling activities for their children in order to enhance desirable behavior of school's students. In line with this study, the study conducted by McCormick, Cappella, O'Connor, and McClowry (2013) stated that participation in home- 
school communication and school-based involvement was less frequent. In addition to this, the study conducted by Dwi Wulandary and Herlisa (2017) revealed that parents have limited comprehension in the typology of Epstein forms of involvement such as parenting, communicating, volunteering, learning at home, decision-making and collaborating with the community. According to Dwi Wulandary and Herlisa, a good relationship between parents and school will foster the children's development in their lea rning and shape their behavior.

How ever, there are several barriers which encounter parent involvement in schooling such as work demands, lack of recognition of the real role of parents as the child's earliest teachers, reluctance to attend the school, lack of communication with the school and parents' perception of their involvement. The finding indicated that parent involvement in schooling processes in the school is low. This implies that majority of parents are not participating in shaping students' school behavior. Therefore, this can be the cause for students' ineffective academic objectives and being undisciplined.

Besides, the key informant interview result identified capacity building problems and poor homeschool interaction as main factors of low level of parent contribution in improving student behavior in the school. Similarly, McCormick et al. (2013) found that examining the interactive effect of parent involvement on children's behavior may be particularly important in low-income communities where parents typically experience less than optimal collaboration with schools.

The study conducted by McCormick et al. (2013) revealed that school-based involvement practices, characterized by behaviors like volunteering at school and engaging with fundraising, are associated with low er levels of student behavioral problems. Social cognitive theory may facilitate understanding of the link between school-based involvement and behavioral problems.

\section{Factors that lead Students to Disciplinary Problems}

\section{School related factors}

Table 3: School related factors that lead students to disciplinary problems

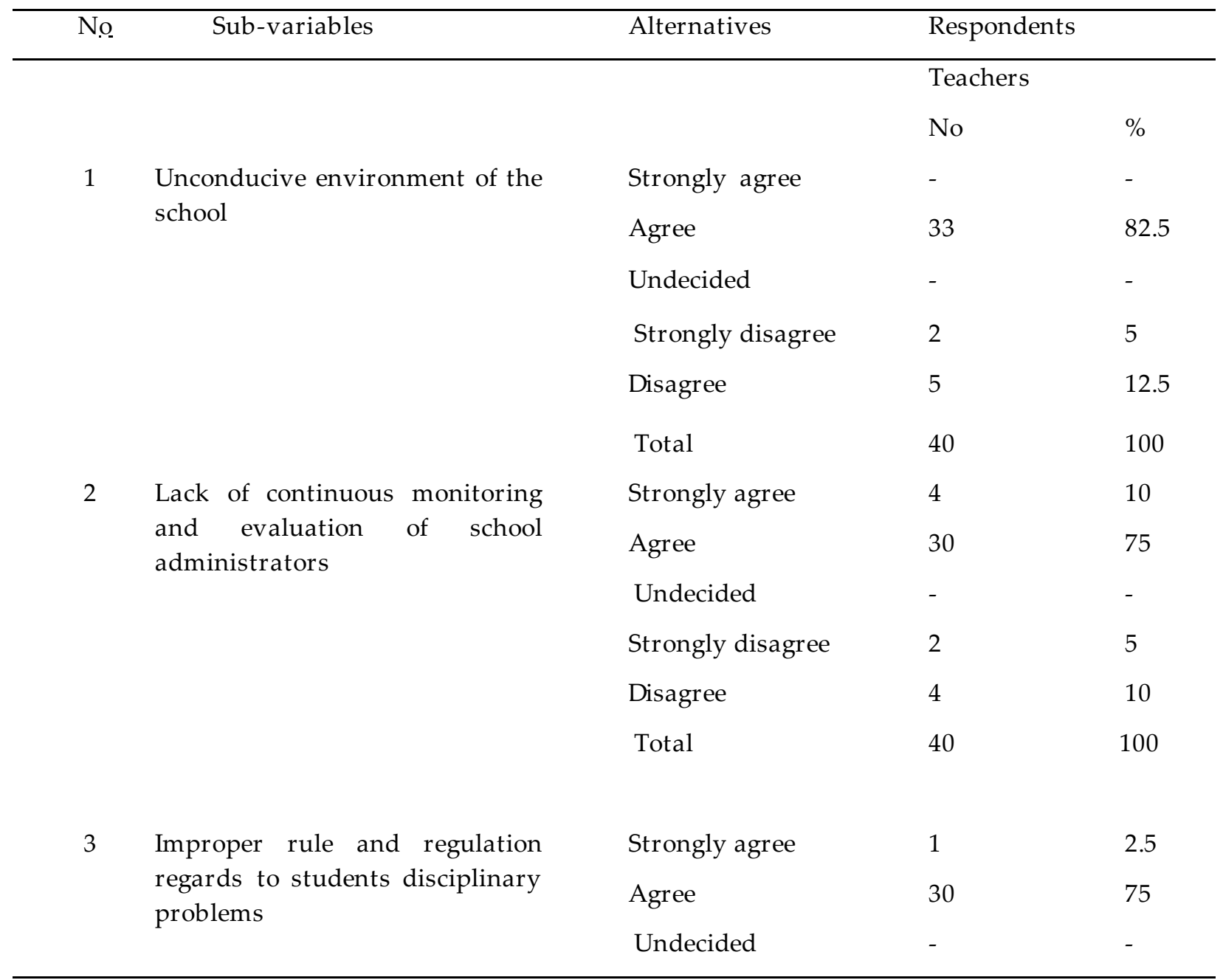




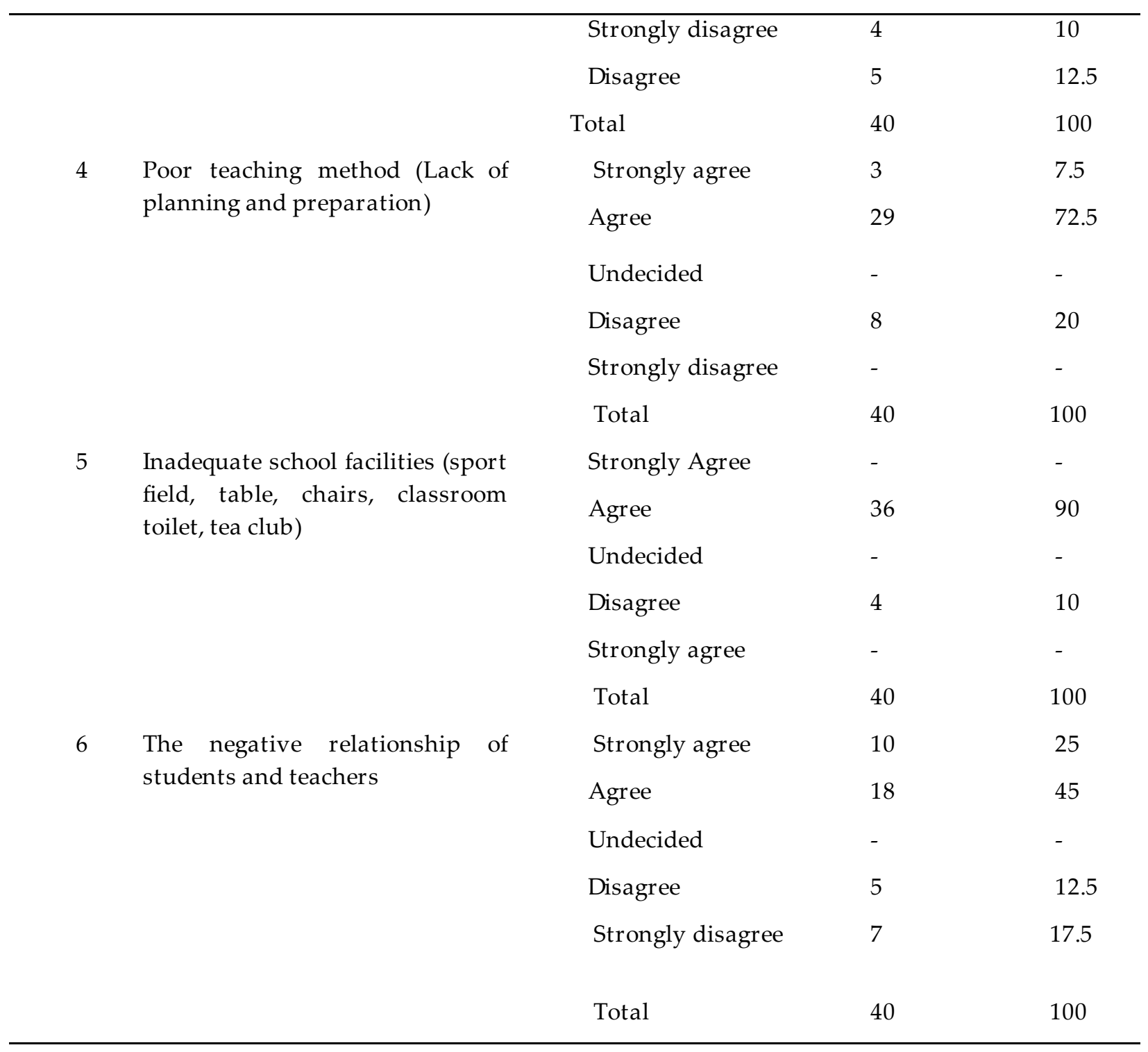

As shown in table 3, sub-variable 1, $82.5 \%$ of teachers agreed that un-conducive environment of the school was cause of student disciplinary problems. This indicates that inconvenience of the school environment can be a cause of student disciplinary problems. The interview result show s that students show disruptive behaviors in the school and in the classroom during teaching-learning process unfavorable school climate. Hernandez and Seem (2004) found that school violence is a reflection of the school climate. The finding identified that annoying, late coming, missing the class, fighting each other, insulting teachers, riot, truancy or excessive absenteeism, lack of interest for doing their homew ork and jumping school fences are disruptive student behaviors experienced in the school. This would, in turn, affect their academic performance and retarded their acceptance at home as well as at school by their teachers, peers and relatives.

Similarly, indiscipline makes students to lose their attention of focusing on educational goals, which are achieved through hard-work, time management, respect for others and self-determination (Gitome et al., 2013). This implies that disciplined pupils are likely to remain focused on their educational goals and aspirations, manage their time well, work harder in academics, and show determination to succeed academically. This is probably because disciplined pupils are less likely to be involved in disciplinary cases which may divert their attention from academic work.

Concerning sub-variable 2, 75\% of teachers were agreed that lack of continuous monitoring and evaluation of school administrators was the cause of student disciplinary problems in the school. This implies that weak school governance was perceived as the factor which motivated students to behave unethically in the school environment. According to McNeal (2014), monitoring has a stronger influence on student behavior than on student attitudes; monitoring significantly reduces absenteeism and truancy, and increases homew ork. 
Regarding sub-variable 3,75\% of teachers agreed that improper rule and regulation regarding to students disciplinary problems in the school is the cause of student misbehavior. Therefore, one can infer that school has improper rules and regulations concerning student behavior. The school leadership has a great role in the teaching learning process and improving students' behaviour in the school. The school managers and teachers themselves were non-punctual; they are not arrived on time to do their assigned tasks. Generally, if the school leadership is strong, automatically, students can attend their class properly.

With regard to sub-variable $4,80 \%$ of teachers confirmed that poor and/or ineffective teaching method is a factor that could bring disciplinary problems in the school. Moreover, other study demonstrates that teacher-student interactive method was the most effective teaching method, followed by studentcentered method while the teacher-centered approach was the least effective teaching method in the classroom. Thus, the teacher-centered method would affect the student's behavior in the classroom (Ganyaupfu E., 2013). The success of the teaching and learning process is determined by the teaching model that describes how the teacher delivers the material to be taught. In this case, the school principals are advised to support teachers in implementing learning innovations and practicing good teaching methods through workshops or home trainings (Qomariyah, 2019). According to Qomariyah, the subject matter knowledge of the teacher, the mode of communication, mode of student- teacher interaction, the intensity of the sound teachers use in the class-room, and the continuous evaluation and monitoring of the school leaders can determine the behavior of students in the school. Therefore, one can infer that poor teaching method (lack of proper planning and preparation, applying teacher-centered approach due to large class size, weak approach of teachers with their students) is seen as a cause which triggered students' into disciplinary problems in the school.

Finding of sub-variable 5 revealed that $90 \%$ of teachers agreed the shortage of school facilities as causes leading students to disciplinary problems. This indicates that school has inadequate facilities which could affect student behavior. In line with this finding, the teaching and learning process in the classroom, the teacher's teaching materials and the books allocated to the students became the references in a teaching and learning process. The researchers also found that the learning materials allocated for students, such as books, were not enough, thus, the students' knowledge were less broad and when they tried to solve the assignments, they got difficulties since the used materials were limited to the student's books. When they needed exercises, the exercises on the book were not enough to cover students' needs (Pratomo, Sarw anto \& Roemintoyo, 2018). Therefore, students lacking school facilities (such as, instructional materials, school toilets, water, chair, recreational centers...) were showing anger in the school.

In sub-variable $6,45 \%$ and $25 \%$ of teachers agreed and strongly asserted that the existence of negative relationship between students and teachers could be an obstacle for shaping studen t classroom behavior in the school. If the teachers had a strong relationship with the students, it was really important to make them closer with another and shape their behavior. This relationship could be performed when the teachers instructed their students with gentle voices. In addition, a teacher must understand the characters of students such as hobby, learning style, and their needs, so they know how to approach them. Consequently, the relationship of the teacher and the student would affect student's academic achievement. Therefore, the connection between teachers and students would be helpful for developing their self-confidence and selfesteem. Thus, the students would be motivated to perform their best in learning and in attitude (Dwi Wulandary \& Herlisa, 2017).

Home related factors

Table 4: Home related factors that lead students to disciplinary problems

Respondents

$\begin{array}{llll}\text { No } & \text { Sub-Variables } & \text { Alternatives } & \text { Teachers }\end{array}$

No $\%$

$1 \quad$ Unusual monitoring of parents

Strongly agree

31

77.5

can be the cause of disciplinary

problems

Agree

Undecided

Disagree

22.5

Strongly disagree 


\begin{tabular}{|c|c|c|c|c|}
\hline & & Total & 40 & 100 \\
\hline \multirow[t]{6}{*}{2} & \multirow{6}{*}{$\begin{array}{l}\text { Base of economic condition } \\
\text { (cash crop or chat, coffee...) }\end{array}$} & Strongly agree & 20 & 50 \\
\hline & & Agree & 10 & 25 \\
\hline & & Undecided & - & - \\
\hline & & Disagree & 10 & 25 \\
\hline & & Strongly disagree & - & - \\
\hline & & Total & 40 & 100 \\
\hline \multirow[t]{5}{*}{3} & \multirow{5}{*}{$\begin{array}{l}\text { Absence of strong relationship } \\
\text { between parents and the school }\end{array}$} & Strongly agree & - & - \\
\hline & & Agree & 30 & 75 \\
\hline & & Undecided & & \\
\hline & & Disagree & 10 & 25 \\
\hline & & Total & 40 & 100 \\
\hline \multirow[t]{6}{*}{4} & \multirow[t]{6}{*}{ Burden of work (home work) } & Strongly agree & - & - \\
\hline & & Agree & 30 & 75 \\
\hline & & Undecided & 4 & 10 \\
\hline & & Disagree & 6 & 15 \\
\hline & & Strongly disagree & - & - \\
\hline & & Total & 40 & 100 \\
\hline \multirow[t]{6}{*}{5} & \multirow[t]{6}{*}{ Pupils are abused at home } & Strongly agree & - & - \\
\hline & & Agree & 16 & 40 \\
\hline & & Undecided & 12 & 30 \\
\hline & & Disagree & 8 & 20 \\
\hline & & Strongly disagree & 4 & 10 \\
\hline & & Total & 40 & $100 \%$ \\
\hline
\end{tabular}

As indicated in table 4 sub-variable 1,77.5\% were strongly asserted that unusual monitoring of parents can be the cause of student's disciplinary problems. Children lacked adequate parental guidance in their character formation can behave unethically in the school. Thus, having insufficient bonding with parents as well as parents who did not monitor, supervise, offer guidance or communicate with their children, or who were either authoritarian or too much permissive were strongly associated with indiscipline (as cited in Wanja, 2014). Besides, poor parental guidance had resulted in students indulging themselves in drug abuse. Drug indulgence, according to Wanja, created a false sense of greatness and power that could explain why rebellion of students occurred accompanied by wanton destruction of property in the school.

In sub-variable $2,75 \%$ were agreed that the bases on economic condition can be a cause of student disciplinary problems in the school. Therefore, this indicates that economic condition strongly affects the student behaviors. Students with high economic status are behaving more unethically than students with low economic condition in the school. Students who came from economically developed families don't care about the interest of their peers who came from the families of low economic background. This can be confirmed that the ideas reflected from students of low economic status are denied by the students whohave more income generated through selling coffee, chat, or both cash crops. This economic disparity between students of the school created negative behavioral atmosphere in the classroom and thereby this would affect the classroom teaching-learning process. 
With regard to sub-variable 3, 75 percent of the respondents agreed that absence of strong relationship between parents and the school is the other home related factor which forced students to misbehave unethically in the school. Traditional views of family-school partnerships tended to focus on parents rather than families, positioned the school as having the primary responsibility for educating children, and situated the locus of action at the school, so that the school was the entity determining the nature of the parental participation. Educators took initiatives in developing activities, meetings, and plans in which parents could participate (Miller, Lines, Sullivan, \& Hermanutz, 2013). These relationships are deemed important not only in the school context, but also in the community environment surrounding the school and its families. The most commonly used term in current literature, however, is family-school partnerships. This term reflects both the reciprocal nature of the relationships and the shared responsibility for educating children. However, family-school partnerships should go well beyond communication in order to develop congruence between home and school in messages, interactions, and activities around education. Evidence from a research synthesis on the effects of teachers' efforts to involve families indicates that students show a number of improved outcomes, including more accurate diagnosis of students' educational placements in classes, reduced numbers of negative behavior reports, and higher achievement scores on reading and math tests (Henderson \& Mapp, 2002).

Concerning sub-variable $4,75 \%$ of respondents agreed that burden of work can be the cause of students' disciplinary problems in the school. This shows that excessive domestic w ork responsibility is the source of student indiscipline in the area. Students with high domestic overload are more vulnerable to disruptivebehaviors in the school. In sub-variable $5,40 \%$ of respondents agreed that abuse of pupils at home is the cause of student disciplinary problems. The home environment had an impact on the discipline of the child. Students, who were victims of some indiscipline behavior, did so because of some personality differences which were a reflection of ineffective socialization. Domestic experiences can lead some students to problematic behaviors. Violent attacks on others and challenge to authority was most likely a result of lack of inbuilt discipline traits in the learners because the parents did not instill a culture of discipline at the tender age of childhood. The study conducted by Wanja revealed that at home where there was a lot of violence between spouses or where the parents corrected their children through harsh punishment like beating or where parents were constantly absent from home, a sense of insecurity and lack of self-esteem developed in the children (Wanja, 2014). Therefore, we can infer that violence at home can be the trigger cause of students' disciplinary problems.

\section{Measures Used to Reduce Students' Disciplinary Problems in the School}

Experienced teachers working in the school believe that:

“While by paying more attention and giving more understanding, parents can minimize the

disruptive behavior of problematic students and change students' attitude tow ards learning

in the school."

One strategy noted during interview showed that teachers focusing on the misbehavior itself, not on the student who misbehaved is the appropriate technique that teachers can use so as to reduce any classroom problem in the school. While handling with misbehavior, one should remember not to humiliate the disruptive student or make him or her to lose face in front of their peers because humiliation attacks student's status in the eyes of his or her peers. Moreover, teacher's stop talking immediately during the time of instruction in the classroom is revealed as another possible method used to minimize students' misbehavior in the classroom. The teacher who stops talking is more likely to get students' attention and increase their awareness. Writing important information on the blackboard with very small letters catches students' attention and makes them ask for reading it.

Additionally, the key informant interview result found that giving rewards and praises for model students are more effective in producing desirable student behavior in the school. Besides, the involvement of students in the formulation of school disciplinary policy has been view ed as a good strategy, which most likely can influence them into accepting and showing commitment tow ards it.

Similarly, the provision of moral leadership and moral education in the schools, value re-orientation in the society, provision of adequate facilities for teaching, reduction of class size, establishment of functional and effective parents-teachers association in schools, positive teacher-student relationship, provision of information communication technologies and internet facilities, high parental and school supervision, counseling and enforceable school rules and regulations, and involvement of students in decision making 
were also identified as possible solutions used to curb student indiscipline in the schools (Ngwokabuenui, 2015).

Furthermore, the interview result conducted with parents revealed that parental beliefs and expectations are crucial in improving home-school relations and shaping student-school behavior. Beliefs about individuals and group characteristics drive our choices and behaviors are crucial in shaping relationships and partnerships. A positive and welcoming school climate, and regular invitations to parents with ways to become involved in their children's education at home and school, positively prompts parents to know about the school's efforts and the behavior of their children. Parents' positive perception highly influences their children's perception of school, which, in turn, positively contributes to students' academic, social, and emotional learning. Parents' expectations regarding with the academic, social, and emotional development of their children have been shown to be among the best determination of school success in the study area. Therefore, parents play a critical role in establishing and maintaining school-family partnerships as well as maintaining positive behavior of school's students. Therefore, this indicates that parents have to be part of the school in developing and shaping the behavior of students in the school.

\section{Factors Affecting Parental Involvement in the School}

Communication is the foundational for most parents, including how they learned about school activities and opportunities, and developed relationships with teachers and staff. It is the key element that shapes parental involvement activities at home and at school, and enhances school-family collaboration. The two-way communication between home and school helps to build an on-going, productive and trusting relationship betw een parents and educators, which increases parent participation in learning activities both at home and at school. This does imply that the individual abilities of the school principals in communication with parents determine the relationship betw een parents and the school. This can build trust and mutual understanding between and among them. In line with this finding, Turney and Kao (2009) found that the importance of schools and classroom teachers is essential in developing appropriate and timely mechanisms to communicate with parents, and bring the importance of mutual respect through communications. Providing communications in languages that parents can understand is essential to developing and maintaining relationships, and in providing opportunities for families. Hence, communication barriers such as noise, misunderstanding and language difficulties can affect the involvement of parents in the affairs of the Azena elementary school (Grade 1-8 in two cycles; primary $1^{\text {st }}$ cycle (Grade 1-4) and primary second cycle (Grade 5-8)).

Cultural intelligence behavior (CIB) could play a significant role in fostering good communication in the school. Cultural intelligence is the individuals' ability to behave effectively in cross-cultural communication. This shows that having intelligence is quite pivotal for students, especially for those who are in their teens. This reinforces the notion that cultural intelligence enables one to identify and understand each other in behaving and acting with different cultures. CIB concerns the individual's ability which is indicated through verbal and nonverbal actions that are appropriate in interacting with people of different cultural backgrounds (Mareta, Sunardi \& Suharno, 2018). According to these researchers, individuals with high behavioral cultural intelligence can adjust their behavior through cross-cultural interaction. How ever, this cultural intelligence behavior in Azena elementary school is less frequent and less emphasized. Besides, factors such as, parents' ignorance to be involved in school activities, assuming the school affairs as the only government responsibility, weak parent-school coordination, weak school governance and carelessness about academic achievement of their children and ineffective communication were identified.

\section{CONCLUSION}

The overall objective of this study is to investigate the role of parents in shaping the behavior of school's students in Azena elementary school. Parent's involvement plays a vital role in implementing the operation of educational system. They can truly make a difference in developing and maintaining desirable behavior of school's students. Their beliefs and expectations are crucial in improving school-family relations and shaping student-school behavior. This study revealed that the contribution of parents in improving student school behavior is low due to multiple factors such as weak parent-school partnership, lack of awareness of parents, and ineffective communication in the study area. Improper rule and regulations, negative relationship between student and teacher, lack of continuous monitoring and evaluation of school administrators, poor teaching method, inadequate school facilities, and un-conducive school environment, 
unusual monitoring of parents and base of students' economic condition are identified as main factors leading students to disciplinary problems in the school. For this, the provision of good ethical leadership and moral education, creating aw areness in the society, provision of adequate school facilities to run effective teaching-learning process, establishment of appropriate parent-school partnership, and enhancing affirmative teacher-student relationship were explored by this study as possible strategies which must be applied in the school. On the same fashion, this study found that giving rewards and prizes for model students, and frequently involving parents in the school affairs are more effective in producing desirable student behavior in the school.

Finally, this study also shows that the presence of communication barriers such as misunderstanding and language difficulties, poor school climate, weak parent-school coordination, weak school governance and leadership, lack of interest of parents for involvement in the school issues, negative perception of parents towards school responsibility (that is, perceiving as the only government responsibility), parents' negative prior experiences with schools, inability of parents to help children with their homew ork, and less focus on cultural intelligence behavior wereidentified as factors which could affect the involvement of parents in the school affairs. Therefore, we can infer that students with involvement of parents in their school tend to have fewer behavioral problems and better academic performance, and are more likely to complete high school than students whose parents are not involved in their school affairs.

\section{RECOMMENDATIONS/SUGGESTIONS}

This study forwards some recommendations to minimize the student disciplinary problems and encourage parental involvement in the school affairs.

* Parents and the school should work cooperatively in order to handle the disruptive problems in the school by preparing frequent meeting programs, conferences and symposiums.

* The school should estabilish a conference and workshop center where teachers are required to contact parents and students together periodically throughout the academic year.

- The school managers and teachers should be punctual to their tasks and be seen as positive examples in the school. This can reduce annoying of students at the every corner of the classroom. Besides this, teachers, who are the core classroom responsibility takers, should create positive relationship with their students in the school.

* Parents should strictly follow up their children day to day activities by contacting with their teachers and asking about their children.

* The school should give prizes and rewards for students who have good conduct, this would reduce student indiscipline in the school.

- The school should set the student disciplinary committee in each and every academic year, and proper school rules and regulations must be established.

- School administrators should open the room for students who misbehave in the classroom to be part of school responsibility takers and one of actors during formulation of school regulations.

* School leadership has to be improved in order to minimize the students' school disciplinary problems and encourage parent involvement in shaping student behavior.

* This study didn't cover all forms of parental involvement in the affairs of the school and didn't address the widest role of parents in improving the behavior of school's students in detail. It also addresses the limited scope in terms of geographical and content coverage. This implies that further study is required. Hence, the study recommends other researchers to further explore the detail roles of parental involvement in order to renovate and improve the existing behavior of the students and examine the causes of student disciplinary problems in the school. Thus, the findings will be more advanced and explored. 
Yigzaw,G.S. (2019). The role of parents in improving the behavior of school's students in Azena primary school, Ethiopia. International Journal of Educational Research Review,4(3),334-349.

\section{REFERENCES}

Creswell, J. W. (2012). Qualitative inquiry and research design: Choosing among five approaches (4th ed.). Thousand Oaks, CA: Sage.

Dwi Wulandary \& Herlisa. (2017). Parent involvement in schooling processes: A case study in an Aceh school. Master's thesis, University of Tampere.

EdSource. (2014). The power of parents, Califormia's students. California: Local Control Funding Formula Overview. Retrived from https://edsource.org/w p-content/publications/Power-of-Parents-Feb-2014.pdf

Epstein, J. L. (1995). School, family or community partnerships: Caring for the Children We Share. PhiDelta Kappan, 76, 701-712.

Epstein, J. L. (2001). School, family, and community partnerships: preparing educators and improving schools. Boulder, CO: West view.

Epstein, J. L. (2010a). School, family or community partnerships: Caring for the children we share. PhiDelta Kappan, 92(3), 81-96.

Epstein, J. L. (2010b). School, family and community partnership: Preparing educators for improving schools (2nd ed.). Boulder: Westview Press.

Epstein, J. L. (2013). Ready or not? Preparing future educators for school, family and community partnerships. Teaching Education, 24 (2), 115-118.

Epstein, J. L. (2016). Necessary but not sufficient: The role of policy for advancing programs of school, family, and community partnerships. Journal of the Social Sciences, 2(5), 202-219.

Epstein, J. L., Galindo, C. L., \& Sheldon, S. B. (2011). Levels of leadership: Effects of district and school leaders on the quality of school programs of family and community involvement. Educational Administration Quarterly, 4(3), 462-495.

Epstein, J.L, Sanders, M., Sheldon, S., Simon, B., Salinas, K., Jansorn, N., et al. (2009). School, family, and community partnerships: Your handbook for action. Thousand Oaks, CA: Corwin.

Epstein, J.L., \& Dauber, S.L. (1991). School programs and teacher practices of parent involvement in innercity elementary and middle schools. Elementary School Journal , 91, 289-305.

Federal Democratic Republic of Ethiopia, Ministry of Education (FDRE, MOE). (2016). Countrywide quality of education evaluation in primary school. Addis Ababa, Ethiopia: Unpublished Raw Data.

Ganyaupfu, E. (2013). Teaching methods and students' academic performance. International Journal of Humanities and Social Science Invention, 2(9), 29-35. Retrieved from http://www.ijhssi.org/papers/v2(9)/Version-2/E0292029035.pdf

Gitome, J. W., Katola, M. T., \& Nyabwari, B. G. (2013). Correlation between students' discipline and performance in the Kenya certificate of secondary education. International Journal of Education and Research, 1(8), 1-10. Retrieved from: http://www.ijern.com/journal/August-2013/33.pdf

Glavin, P. (2002). Behavioral strategies for classroom management. Columbus, Ohio: Charles E. Merrill Publishing Company.

Grusec, J. E. (2011). Socialization processes in the family: Social and emotional development. . Annual Review of Psychology, 62 (1), 243-269. doi: 10.1146/annurev.psych.121208.131650. .

Hall, N., \& Quinn, R. . (2014). Parental involvement at the high school level: Parents' perspectives. Journal of Ethnic and Cultural Studies, 1(1), 13-21.

Henderson, A. T., \& Berla, N. . (1994). A new generation of evidence: The family is critical to student achievement. Washington D.C: National Committee for Citizens in Education.

Henderson, A. T., \& Mapp, K. L. (2002). A new wave of evidence: Impact of school, family, and community connections on student achievement. Austin, TX: SEDL.

Hernandez, T. \& Seem S.R. (2004). A safe school climate: A systematic approach and the school counselor.

Herrell, P. O. (2011). Parental involvement: Parent perceptions and teacher perceptions. Doctoral dissertation. Retrieved from PrQquest Dissertations and Theses. .

Hill, N. E., \& Tyson, D. F. (2009). Parental involvement in middle school: A meta-analytic assessment of the strategies that promote achievement. Developmental Psychology, 45, 740-763. Doi: 10.1037/a0015362. 
Yigzaw,G.S. (2019). The role of parents in improving the behavior of school's students in Azena primary school, Ethiopia. International Journal of Educational Research Review,4(3),334-349.

Hill, N. E., \& Taylor, L. (2004). Parental school involvement and children's academic achievement: Pragmatics and issues. Current Directions in Psychological Science, 13(4), 161-164. Retrieved from https://amshq.org/ /media/Files/Publications-and-Research/ResearchLibrary/Action Research/Loomans.ashx?l

Jones, L. N. (2014). Barriers to parental involvement for children at risk. Doctoral dissertation: ProQuest Dissertations Publishing, Accession no. 3579639.

Kothari, C.P. 2006. Research Methodology: Methods and Techniques. New Age International Publishers, New Delhi. Leitch, M. L., \& Tangri, S. S. (2006). Barriers to home-school collaboration. Educational Horizons, 67, 70-74.

Loomans, M. G. (2014). Parent involvement that supports children academically and promotes the development of independence. Master's thesis.

Retrieved from https://minds.wisconsin.edu/bitstream/handle/1793/70157/MichelleLoomans.pdf? sequence=1

Mareta, V. U, Sunardi \& Suharno. (2018). An analysis of students' cultural intelligence: A case study at the state junior high school (SMPN) 20 of Surakarta. International Journal of Educational Research Review, 4(1), 76-81.

McCormick, M., Cappella, E., O'Connor, E., \& McClowry, S. (2013). Parent involvement, emotional support and behavior problems: An ecological approach. The Elementary School Journal, 114(2), 277-300: University of Chicago Press. Retrieved from https://steinhardt.nyu.edu/scmsAdmin/media/users/sm6/McCormick_2013_parent_involvement.pdf

Miller, G. E., Lines, C., Sullivan, E., \& Hermanutz, K. (2013). Preparing educators to partner with families. Teaching Education, 24 (2), 150-163.

Mwirichia, V. (2013). Influence of parental involvement on academic performance of preschool children in Kangeta Division. Master's thesis, University of Nairobi. Meru County, Kenya.

Newchurch, A. (2017). The impact of parental involvement on student success: School and family partnership from the perspective of parents and teachers. Doctoral dissertation. Kennesaw State University. Retrieved from https://digitalcommons.kennesaw.edu/cgi/viewcontent.cgi?article=1022Econtext=teachleaddoc_etd

Ngw okabuenui. P. (2015). Students' indiscipline: Types, causes and possible solutions: The case of secondary schools in Cameroon. Journal of Education and Practice, 6(22). Retrieved from https://files.eric.ed.gov/fulltext/EJ1079558.pdf

Okeke, C. C. (2014). Effective home-school partnership: Some strategies to help strengthen parental involvement. South African Journal of Education, 34(3), 1-9.

Papaoikonomou, A. (2017). The impact of political socialization on students' behavior: Empirical research in schools of Central Macedonia in Greece. International Journal of Educational Research Review, 2(2), 1-10.

Pratomo, A., Sarwanto \& Roemintoyo (2018).The development of integrative theme based instructional materials containing characteristics values of fifth grade elementary schools in Surakarta, Indonesia. International Journal of Educational Research Review, 3(3), 39-46.

Qomariyah, S. N. (2019).Effect of problem based learning model to improve student learning outcomes. International Journal of Educational Research Review, 4 (2), 217-222.

Rahimi, M., \& Karkami, F. H. (2015). The role of teachers' classroom discipline in their teaching effectiveness and students' language learning motivation and achievement: A path method. Iranian Journal of Language Teaching Research, 3(1), 57-82.

McNeal, J. (2014). Parent involvement, academic achievement and the role of student attitudes and behaviors as mediators. University of Connecticut, Storrs. Universal Journal of Educational Research, 2(8), 564-576. Doi: 10.13189/ujer.2014.020805. Retrieved from file://E:/2011\%20E.C/Journal\%20publishers/School\%20community\%20journal/APA\%20FORMAT /EJ1053945.pdf

Ravitch, D. (2016). The death and life of the great American school system: How testing and choice are undermining education. New York, NY: Basic Books. Retrieved from https://tampub.uta.fi/bitstream/handle/10024/102137/GRADU-1507560787.pdf? sequence=1

Tadesse Abera. (2014). Practices, challenges and prospective of primary school physical education teachers in selected schools of Debre Birhan. Master's thesis, Addis Ababa University. Addis Ababa.

Turney, K., \& Kao, G. (2009). Barriers to school involvement: Are immigrant parents disadvantaged?. The Journal of Educational Research, 102 (4), 257-271. 
Wanja. G. (2014). The role of parents in resolving students' discipline problems in public day secondary schools in Kikuyu Sub County. Kiambu County, Kenya, Master's thesis, Kenyatta University .

World Bank. (1996). Improving basic education in Pakistan: Community participation, system accountability, and efficiency. Population and Human Resources Division, Country Department I, South Asia. Washington, D.C: World Bank.

\section{Annex 1 \\ Questionnaire for Teachers}

\section{Dear respondents}

This questionnaire and interview is prepared to collect data for this article paper. The purpose of this research is to investigate the role of parents in shaping students school behavior in Azena primary school and thereby to suggest some feasible strategies that would help to reduce the ethically problems in the study area.

The information collected will be purely for academic purpose (exercise). I assure you that all your responses will be totally held confidential. Your names will not be used in my report. Thus, you are kindly requested to give genuine and accurate answers to the questionnaire in a freely and openly manner. So, your genuine responses for the following questions are extremely important for the successful accomplishment of this article paper.

Thank you for your informed consent and genuine responses!

Yours' sincerely,

Gedifew Sew enet Yigzaw

General instruction: Read the following items and respond to each question by putting a mark $(\sqrt{ })$ to your choice and/or providing a short answer where necessary. Please, do not leave the open ended questions unanswered.

Part I: Demographic data

1. Gender Male

2. Age 21-30

$\square \quad$ Female

3. Educational qualification

Certificate

Diploma

$\square \quad 41-50$

4. The level of parent involvement in improving the behavior of school's students in the school?
A) High
B) Medium
C) Low

5. What factors do affect parent involvement in the school affairs?

6. To what extent do parents carryout their responsibility in reducing the causes of students' disciplinary problems in your schools?

7. Describe the nature of home-school partnership of your school?

8. What are the strategies that could be employed in developing good students' behavior in the school?

Part 3: Questions related with causes of student's disciplinary problems

Strongly agree $=\mathrm{SA} \quad$ Agree $=\mathrm{A} \quad$ Undecided $=\mathrm{Un} \quad$ Disagree $=\mathrm{D} \quad$ Strongly disagree $=\mathrm{SD}$

School related factors/Causes 


\section{No. Sub-variables}

1 Un-conducive school environment

2 Lack of continuous monitoring and evaluation of school administrators

3 Un proper rule and regulation regards to students disciplinary problems

4 Poor teaching method (Lack of planning and preparation)

5 Inadequate school facilities (sport field, table,

6 chairs, classroom toilet, tea club etc.) the negative relationship of student teacher (Dislike to a teacher or hostility towards a teachers)

\section{Home related factors}

\section{No Sub-variables}
Unusual monitoring of parents
2 Base of economic condition (cash crop area, chat, coffee ...
3 Lack of strong relationship between parents and schools
4 Burden of work (homework, parent responsibilities ... etc.)
5 Pupils may be abused at home.

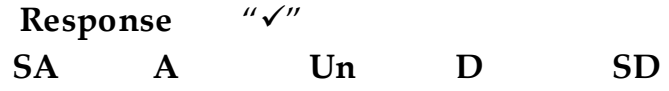

\section{Response " $\checkmark$ "}

$\begin{array}{lllll}\text { SA } & \text { U } & \text { Un } & \text { D } & \text { SD }\end{array}$

9. What impacts do the other student disciplinary problems have on the other students' behavior?

10. What strategies should be set to reduce the students' disciplinary problems in your schools?

11. Suggest other best practices of handling student disciplinary problems found in the school? 